\title{
Measuring a farm's profitability after adopting precision agriculture technologies: A case study from Italy
}

\author{
Giorgia Bucci ${ }^{1}$, Deborah Bentivoglio ${ }^{1}$, Matteo Belletti ${ }^{1}$, Adele Finco ${ }^{1}$ \\ ${ }^{1}$ Department of Agricultural, Food and Environmental (D3A), Marche Polytechnic University, Ancona, Italy
}

\section{ABSTRACT}

Precision agriculture (PA) offers the opportunity for farmers to improve both efficiency in managing resources and optimisation of process inputs, thus increasing their whole farm's profitability. Despite these well-known benefits, the adoption of PA technologies (PATs) is still challenging due to socio-economic barriers and unique characteristics of the farms: cropping systems, technical developments, field sizes and farm scale. The economic aspect is undoubtedly one of the most important aspects to consider before adopting PATs. In most of the cases, farmers are reluctant to introduce precision farming systems since the costs and uncertainty about the profitability and advantages need to be addressed. This study aims to explore how PATs could affect the profitability of a representative Italian farm specialising in the production of cereals, making this a case study. In detail, an economic analysis was applied to determine the profitability of the farm, which showed that the adoption of PAT's increased the yield of durum and soft wheat and significantly reduced the cost of mechanical operations and technical means. Therefore, the potential gains from the adoption of PATs challenges policymakers to design targeted interventions which could encourage their uptake. This paper is an extended version of the original contribution presented to the 2019 IEEE International Workshop on Metrology for Agriculture and Forestry (MetroAgriFor) in Portici, Italy.

\section{Section: RESEARCH PAPER}

Keywords: Precision Agriculture, Measurement; Cost-benefit analysis; Profitability, Case study research

Citation: Giorgia Bucci, Deborah Bentivoglio, Matteo Belletti, Adele Finco, Measuring the farm's profitability after the adoption of Precision Agriculture Technologies: A case study research from Italy, Acta IMEKO, vol. 9, no. 3, article 11, September 2020, identifier: IMEKO-ACTA-09 (2020)-03-11

Section Editor: Mauro D'Arco, University of Naples Federico II, Italy

Received March 9, 2020; In final form August 31, 2020; Published September 2020

Copyright: This is an open-access article distributed under the terms of the Creative Commons Attribution 3.0 License, which permits unrestricted use, distribution, and reproduction in any medium, provided the original author and source are credited.

Funding: This work was supported by the Rural Development Programme (RDP) of Marche Region 2014-2020, which financed the Operational Group (OP) S.A.T. (SMART AGRICULTURE TEAM) - Precision agriculture: reduction of the environmental impact of production systems (ID N²9000).

Corresponding author: Deborah Bentivoglio, e-mail: d.bentivoglio@univpm.it

\section{INTRODUCTION}

As a means of producing on-site data to guide decisionmaking, precision agriculture (PA) is a whole-farm management approach that allows for managing crops growth for better yield and quality through measuring physical parameters and collecting data [1]. Starting in the 1990s, several definitions of PA have been given in the literature, [2]-[6], but all the authors agree that this practice allows the site-specific management of the agronomic inputs and practices within a field through accurate measurements [7]. In detail, we can consider PA as integrated information and as a production-based farming system, designed to deliver high-end technology solutions to increase farm production efficiency and profitability while minimising environmental impacts. PA technologies (PATs) are all those innovations that incorporate recent advances in modern agriculture, providing evidence for lower production costs, increased farming efficiency and reduced impacts. Accuracy and precision are two relevant factors to consider when taking data measurements. They both reflect how close a measurement is to an actual value, but accuracy refers to how close a measurement is to a known or accepted value, while precision reflects how reproducible measurements are.

For a long time in the field of PATs, digital devices, which can take more accurate and precise measurements, generally corresponded to higher investment costs. This economic constraint initially caused a limited diffusion of PA. Today, however, there are a wide range of different low-cost devices is available on the market that allow for meeting measurement accuracy requirements. Further, policymakers at the national and European level have established a set of measures and initiatives to encourage and facilitate the purchase and use of digital technologies, including PATs, throughout the agri-food supply chain (Figure 1). 
EUROPEAN OPPORTUNITIES TO SUPPORT PA

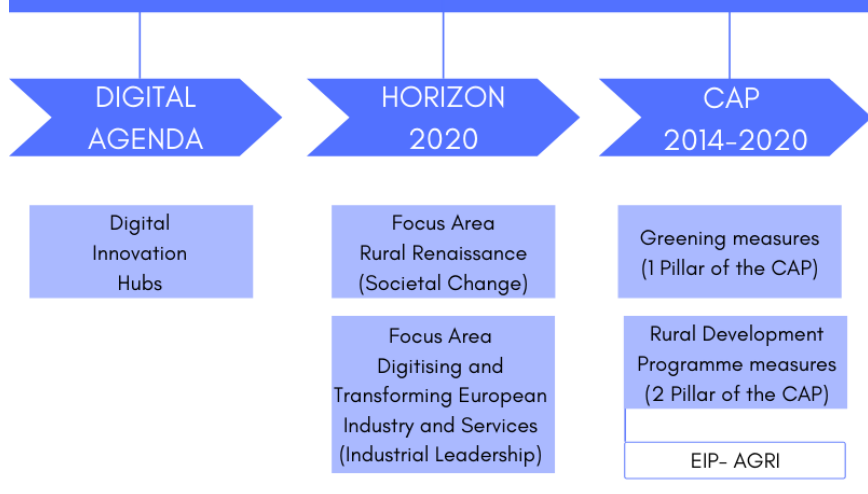

NATIONAL INITIATIVES TO SUPPORT PA

POLICY INITIATIVES ON DIGITISING INDUSTRY

\begin{tabular}{|c|}
\hline FRANCE \\
Industrie Du Future \\
Investment d'Avenir \\
\hline GERMANY \\
Platform Industrie 4.0 \\
Allianz Industrie 4.0 \\
It's OWL \\
\hline ITALY \\
Industria 4.0 \\
Transizione 4.0 \\
\hline
\end{tabular}

\begin{tabular}{|c|}
\hline BELGIUM \\
Made Different \\
Marshall 4.0 \\
SPAIN \\
Industria Connectada \\
4.0 \\
\hline PORTUGAL \\
Industria 4.0 \\
\hline CZECH REPUBLIC \\
Prumysl 4.0 \\
\hline
\end{tabular}

\begin{tabular}{|c|}
\hline NETHERLANDS \\
Smart Industry \\
\hline DENIMARK \\
MADE \\
\hline AUSTRIA \\
Smart Industry \\
\hline SLOVAKIA \\
Smart Industry (SK) \\
\hline HUNGARY \\
IPAR 4.0 platform \\
\hline
\end{tabular}

Figure 1. Policy instruments for PATs adoption

From European level, on 19 April 2016, the European Commission launched the first industry-related initiative known as the Digital Single Market strategy, part of the Digital Agenda, aiming to make the agriculture sector and rural areas of Europe digitised and data-empowered. Another fundamental contribution to the diffusion of these technologies is mainly provided under Horizon 2020 through the Societal Challenges and Industrial Leadership pillars.

However, when we refer to implementation and adoption of PATs by end-users, and then by farmers, this is mostly channelled through the EU's Common Agricultural Policy (CAP). For instance, different rural development measures under pillar II of CAP can foster the development of these technologies. PA can contribute to meeting the requirements put forward within the greening measures (pillar I of CAP) in which farmers receive payment to undertake practices that benefit the environment and the climate.

At the national level, each member state of the EU has developed Industry 4.0 policies to strengthen industrial competitiveness and modernise the manufacturing and agriculture sectors. This policy especially supports the digitalisation of agriculture based on the development and introduction of new tools and machines in the production process.

However, even if there are affordable PATs available on the market and policy support for the acquisition of the technologies, the application remains circumscribed at few farms. In fact, in addition to the cost of investment, the adoption of the PATs has encountered other difficulties, such as additional application or management costs and investment on new equipment, employee training for using the technologies and uncertainties found within the farming community [8]-[14]. Given these premises, this paper discusses the economic benefits of PA, as they concern the accuracy of the measurements taken by different technologies, while trying to answer the following question: "What is the economic effectiveness deriving from the adoption of high-accuracy PATs?". To reach this goal, we attempt to quantify the economic benefits of PA based on a case study - a representative cereal farm in central Italy that manages the whole-farm system with a mixed approach of conservation agriculture and precision farming. The case study method allows researchers to explore and investigate a contemporary real-life phenomenon through a detailed contextual analysis of a limited number of events or conditions and their relationships. The methodology adopted for evaluating the profitability, the costbenefit analysis, derives from the introduction of PATs. This paper extends a previous study presented during the 2019 IEEE International Workshop on Metrology for Agriculture and Forestry (MetroAgriFor) in Portici, Italy. Here, a more extensive and detailed economic analysis is provided by the authors. The remainder of the paper is organised as follows: section 2 shows the primary precision farming tools and their adoption. Section 3 presents a brief literature review on the profitability of PA. Section 4 provides the methodology and data, and section 5 discusses the results. Finally, the conclusions and some policy implications are detailed in section 6 .

\section{PRECISION AGRICULTURE TECHNIQUES AND TECHNOLOGIES}

Rather than referring to the development of new digital technologies, PA refers to the need to collect geo-referenced information necessary to monitor or manage spatially variable agricultural fields. In fact, PA is a management concept based on observing, measuring and responding to intra-field variability in crops through the use of technology. PATs allow farmers to recognise variations in the fields and to apply variable-rate treatments with a greater degree of precision than before [15][16]. The management of PA can be divided into four phases (Figure 2):

1. Understanding and identifying variability

2. Determination of homogenous zones

3. Decisional Phase

4. Agricultural Operation Management

Each of these phases requires specific technology.

To achieve a better understanding of within-field variability, there is a set of different instruments and tools that allow farmers to generate and manage big data from the field. The development and implementation of PA has been made initially possible by combining the Global Positioning System (GPS) and geographic information systems. These technologies allow the combination of real-time data collection with positional information. Remote and proximal sensing are the two most common techniques used for the acquisition of information related to variability within crop fields. Satellite, airborne or UAV platforms, using different type of cameras, are the most popular technologies used in agriculture. In terms of proximal sensing, in which the sensor is close to the object to be monitored, it is possible to directly analyse soil and crop data in real-time. Typical examples of proximal sensing are as follows:

- Watermark and Sentek soil moisture sensors - used measuring soil humidity. 


\section{1) UNDERSTANDING AND IDENTIFYING VARIABILITY}

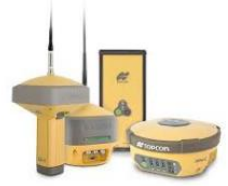

GPS

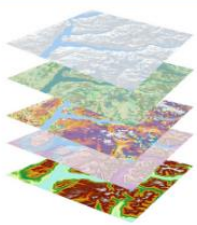

GIS

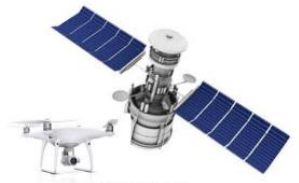

REMOTE

SENSING
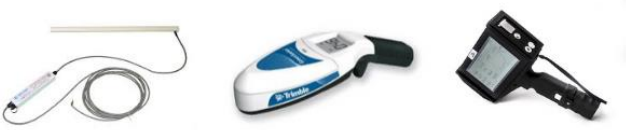

PROXIMAL SENSING

\section{2) DETERMINATION OF HOMOGENOUS ZONES}

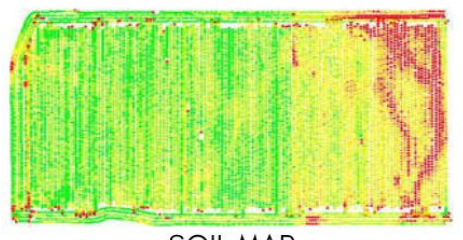

SOIL MAP

\section{3) DECISIONAL PHASE}

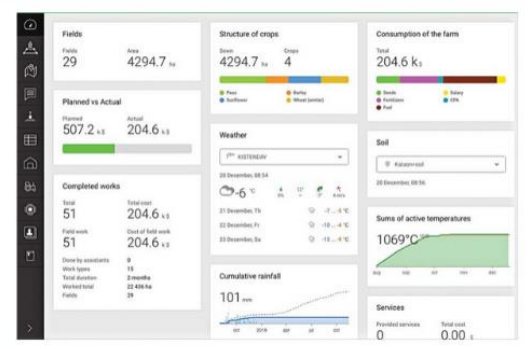

DSS

\section{4) AGRICULTURAL OPERATIONS MANAGEMENT}

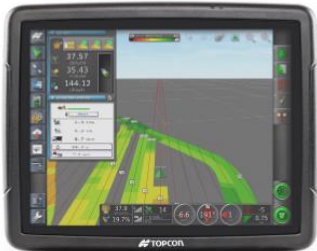

ISOBUS

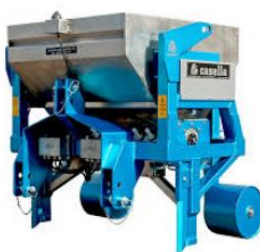

VARIABLE RATE APPLICATION
Figure 2. Technologies for PA

- The Green Seeker system - used to measure the normalised difference vegetation index and to quantify crop variability via optical sensors;

- On-harvester grain quality sensors - sued to estimate protein, oil and moisture within the grain by using infrared spectroscopy.

By collecting this data from different sensors, farmer can be aware of the spatial and temporal variability of the fields, as represented through maps, and it is possible to recognise homogeneous areas within a field that could be treated in a diversified way. All the data collected from the sensors and maps can be stored in a decision support system (DSS), a softwarebased system that allows farmers to analyse all the agricultural data and consider them as inputs for the decision-making process [17]. After the decision phase, the farmer is therefore ready to intervene in the field through the use of advanced agricultural machinery with serial control and communications data network (commonly referred to as "ISO Bus" or "ISOBUS"), the standard protocol that makes it possible to manage the communication between tractors, software and equipment of major manufacturers, allowing the exchange of data and information with a universal language through a single control console in the tractor's cab [18]. Another suitable application for agricultural operations management is variable-rate technology, which provides the capability to vary the rate of soil- and crop-applied inputs for site-specific applications. These technologies consent the recording of spatial differences in relevant factors to crop growth, such as the quality of soil, availability of water and fertilisers, and crop yield. This greatly improves the efficiency of resources and adjustability of biological-technical systems as well as leads to reduced waste of inputs.

Other studies highlight how positioning accuracy represents a key factor for the precise management of agricultural operations [19], [20]. In the engineering field, accuracy refers to how close a measurement is to the true value, but a more rigid definition is applied by the International Organization for Standardization (ISO), which defines accuracy as a measurement with both true and consistent results. The ISO definition means that an accurate measurement has no systematic error and no random error. A key component of the precision farming management approach is the use of a wide array of digital devices that allow taking accurate agricultural measurements, including GPS guidance, sensors, control systems, robotics, drones, autonomous vehicles, variable rate technology, GPS-based soil sampling, automated hardware, telematics and software.

PA applications can be classified into three categories, taking into account the different degree of accuracy in the positioning systems [21]:

- Low accuracy (meter level) - used for asset management, tracking and tracing;

- Medium accuracy (sub-meter level) - used for tractor guidance, via manual control, for lower accuracy operations such as spraying, spreading, harvesting bulk crops and area measurement/ field mapping;

- High accuracy (cm level) - used for auto-steering systems on tractors and self-propelled machines, like harvesters and sprayers.

These technologies also differ in cost and the knowledge or skills required to use the tool. Proximity sensors, depending on the type of sensor, have a commercial price between 50-60€ (Watermark sensor) up to $1,000 €$ (Sentek Sensor). A drone for professional agricultural use has an average cost of $5,000 €$, while a tractor ISOBUS application via the automatic steering systems can cost up to $20,000 €$. Considering these relatively high costs and the skills needed to manage technologies, which not all farms still have, technology providers are increasingly making these technologies available as services. This is the case for yield maps or DSSs, which are generally made available in the form of annual fees, depending on the services requested. The use of technologies as a service is a way to reduce the costs of technology and to spread their use among farmers who possess knowledge gaps regarding management of the equipment.

Focusing on the adoption of PATs at worldwide level, the US is the top player in this sector, followed by Australia and Canada. Nevertheless, the percentage of PA adoption has increased in Europe, with a rate of $15-20 \%$. Based on region, the EU PA 
market is segmented into the UK, Germany, Spain and France. In Italy, only $1 \%$ of the agricultural surface is managed through precision farming techniques.

The work of [22], focused on the level of adoption of PA among Italian farmers, showed that PATs adopters were characterised by an average farm size of 143 ha, showing that farmers are more likely to manage big farms with AP. In line with these results, it is possible to highlight that PA follows the model of a capital-intensive technology, characterised by both high entry and large fixed transaction costs, and by an overly long payback period. However, although the adoption rate of technology among farmers is still low due to these socioeconomic barriers [23]-[26], the market for smart agriculture technologies is growing since technology providers are increasingly developing solutions that can cover the entire field of the agri-food supply chain (AFSC). In particular, most of the solutions cover the first step of AFSC, the production phase, from cultivation to storage of the product to processors. According to a recent survey, currently, the available technologies on the market are those that support the growing phase of the crop (79\%) followed by seeding/plantation phase (37\%) and harvesting (33\%) [27].

The most widespread technologies on the market are related to the soil mapping (29\%), machine control (27\%) and precision interventions $(21 \%)$, such as planting, fertilising and distributing pesticides. The remaining part of these technologies are reserved for farm and crop management and monitoring (18\% and $5 \%$, respectively). The main crops treated with PA are fruit and vegetables $(38 \%)$, cereals (35\%), grapes $(23 \%)$ and olives (4\%) [28]-[30]. For fruit and vegetable crops, machine vision methods allow growers to grade products as well as monitor food quality and safety with automation systems recording parameters related to product quality (colour, size, shape, external defects, sugar content, acidity, etc.). Additionally, the tracking of field operations, such as the chemicals sprayed and use of fertilisers, can provide for a complete fruit and vegetable processing method. The use of PATs on arable land is one of the most successful applications and is the most advanced amongst farmers. The technology allows farmers to control the number of inputs in arable lands, such as the optimised amounts of fertilisers like nitrogen, phosphorus and potassium. The development and adoption of PATs and methodologies in grape and olive orchards are more recent than in arable lands. For these high-value crops, precise irrigation methods are developing rapidly to save water while improving yields and fruit quality; for example, grape quality and yield maps are of great importance during harvest to avoid mixing grapes of different potential wine qualities [31]. The "Guidelines for the development of precision agriculture in Italy" [32] calls for expanding management through precision agriculture to up to $10 \%$ of the agricultural area cultivated nationally by 2021 . Therefore, it becomes essential to identify the factors limiting their diffusion and to analyse profitability from using these technologies.

\section{THE PROFITABILITY OF PRECISION AGRICULTURE: A BRIEF REVIEW}

Three different PA research focus areas are represented in the literature [33]: studies aiming to prove the profitability and the positive environmental impacts of PA [34]-[38], studies investigating the technical aspects of product development and process improvement, and studies focusing on the implementation of PA at the single-farm level. In the first research focus area, PA has the potential to help farmers improve input allocation decisions, thereby lowering production costs or increasing outputs and, potentially, increasing profits. However, there is still scant knowledge about the relative magnitude of the overall costs and benefits of PATs on individual farms.

Previous studies [39]-[44] tried to evaluate the savings and revenues caused by $\mathrm{PA}$, but only by considering either the average savings from the application of a single technology or a specific growth phase of the crop (Table 1)

According to [45], the impact of PATs on agricultural production is expected in two areas:

- Profitability for farmers;

- Ecological and environmental benefits to the public.

However, both the profitability and the environmental benefits of PA continues to be difficult to predict, evaluate and measure [46], [47]. According to the literature, the profitability of PA depends on different aspects, including farm size, the type of crop, the technology adopted, the degree of spatial variability of soil attributes (e.g. soil types, fertility and organic matter) and yield response [48]-[53]. Studies on PAT adoption emphasise that adopters tend to operate a larger agricultural area and subsequently generate a higher income. This indicates the ability to accommodate some risk in investment of newer and larger technologies. Some studies have highlighted that farms specialising in high-income crops, such as vineyards and olive groves, are more likely to adopt PATs.

The major benefits of PA management derive from the increase of crop yields and reduced inputs as well as more efficient farm management with improved communication possibilities and higher quality of work with machine-guided systems. The implementation of precision farming concepts may mitigate production risks because inputs are applied only where they are needed. While risk mitigation with precision farming is intuitive, the implementation of precision farming typically requires substantial investments that may increase financial risk [54]. Investments in precision farming are further associated with the irreversibility of the capital cost, which should be taken into account where appropriate; farmers might prefer to wait for better information on the costs and benefits of the new technology before investing in precision farming technologies [55]. While the costs of precision farming technologies can, in

Table 1. Economic benefits of PA

\begin{tabular}{|c|c|c|c|c|c|}
\hline Year & Author & PATs & $\begin{array}{l}\text { Case } \\
\text { study }\end{array}$ & Crop & $\begin{array}{l}\text { Average } \\
\text { savings }\end{array}$ \\
\hline 2000 & $\begin{array}{c}\text { Bongiovanni \& } \\
\text { Lowenberg- } \\
\text { DeBoer }\end{array}$ & $\begin{array}{c}\text { RTV for } \\
\text { fertilisation }\end{array}$ & USA & $\begin{array}{l}\text { Soya and } \\
\text { corn }\end{array}$ & $17.60 € /$ ha \\
\hline 2003 & Godwin et al. & $\begin{array}{l}\text { Assisted/Sem } \\
\text { i-Automatic } \\
\text { Driving }\end{array}$ & UK & $\begin{array}{l}\text { Arable } \\
\text { crops }\end{array}$ & $25 € /$ ha \\
\hline 2003 & Godwin et al. & CTF & UK & $\begin{array}{c}\text { Soft } \\
\text { Wheat }\end{array}$ & $\begin{array}{l}\text { From } 18 \text { to } \\
45.5 € / \text { ha }\end{array}$ \\
\hline 2009 & $\begin{array}{l}\text { Biermacher et } \\
\text { al. }\end{array}$ & $\begin{array}{c}\text { RTV for } \\
\text { fertilisation }\end{array}$ & USA & $\begin{array}{c}\text { Soft } \\
\text { Wheat }\end{array}$ & $13.2 € /$ ha \\
\hline 2010 & Wagner et al. & $\begin{array}{c}\text { RTV for } \\
\text { fertilisation }\end{array}$ & $\mathrm{DE}$ & $\begin{array}{c}\text { Soft } \\
\text { Wheat }\end{array}$ & $16 € /$ ha \\
\hline 2011 & $\begin{array}{l}\text { Robertson et } \\
\text { al. }\end{array}$ & $\begin{array}{c}\text { RTV for } \\
\text { fertilisation }\end{array}$ & AUS & $\begin{array}{l}\text { Arable } \\
\text { crops }\end{array}$ & $9.4 € /$ ha \\
\hline 2012 & Shockley et al. & $\begin{array}{l}\text { RTV for } \\
\text { seeding }\end{array}$ & USA & $\begin{array}{l}\text { Soya and } \\
\text { corn }\end{array}$ & $31.67 € /$ ha \\
\hline
\end{tabular}


many cases, be estimated precisely, it is more challenging to evaluate the benefit of the system in management.

The willingness of farmers to trust the technology is a fundamental behavioural factor in achieving positive results. Several studies found that a low level of trust in the technology could be a key limitation for PAT adoption when compared to other factors. Thus, farmers are waiting for research results on the profitability of various PATs before deciding to invest significantly to adopt new technologies. On the one hand, PA is aimed at large holdings with a farm and capital structure that enables them to invest in expensive systems. On the other hand, it is a means to move farm management back to small-scale farming processes with detailed knowledge about small units and management zones. It enables farmers to treat each unit, whether it is a piece of land or an animal, with the same care as farmers did in previous times. This development is facilitated by the help of smart technologies that allow the farmer to gain detailed knowledge about the field and subsequently treat the field accordingly. Despite these advantages, PA is adopted only by innovative farmers and the intelligent usage of precision farming data is still rather limited. The introduction and uptake of technologies require new skills and knowledge for farmers and advisers. Raising awareness and organising training on a regional/local level is essential, especially to reach small and medium-sized farms where the use of digital technologies is not always thought of as profitable

However, taking advantage of PATs will depend not only on the willingness of farmers to adopt new technologies but also on each farm's potential, in terms of scale economies, since profit margin increases with farm size. This concept is widely explained in the work of [56], which analysed the socio-cultural and complexity factors that affect the probability of an Italian farmer adopting new PATs. The authors found that the farmers most prone to technological innovation all had similar characteristics: big size farms (average dimension equal to 143 hectares) and young managers with the highest level of education.

\section{DATA AND METHODS}

To determine the profitability of applying PA, a case study was conducted. According to [57], the case study research method is 'an empirical inquiry that investigates a contemporary phenomenon within its real-life context; when the boundaries between phenomenon and context are not clearly evident; and in which multiple sources of evidence are used.' Due to the limited availability of other cases for replication, in this study, we adopt a single-case design. While not reflecting a statistical representation, a single-case study can contribute to scientific development through a deep understanding of a still-rare context of inquiry, such as that of adopting PATs in the Italian agriculture sector.

Cost-benefit analysis was selected evaluate the economic implications of adopting PATs and was carried out on an innovative farm specialising cereals production located in the centre of Italy. This study, conducted in 2019, takes into consideration durum wheat and soft wheat production on an agricultural area of 537 flatland hectares applying a conservative production system (i.e., sod seeding). The farmer was interviewed and asked to characterise the farming practices before and after the adoption of PATs. Also, specific questions were asked to find out the technological investments. From 2010 to 2016, the farm has invested in highly accurate PATs, costing approximately $184.000 €$, to be used to make decisions with greater precision and to optimise crop yields. The main investments include assisted steering (ISOBUS); services for georeferencing, production and soil mapping system; a variable rate fertiliser spreader; machinery for weeding; and treatment with variable dosage distribution. The description of the phases of the cost-benefits analysis are follows:

1) Definition of the time horizon under study:

- 2005-2009 - pre-adoption period;

- 2010-2016 - progressive investment period in the PA technological 'package';

- 2013-2017 - post-adoption (progressive) period of the PA package.

2) Definition of average land productivity (both for durum wheat and soft wheat):

- for pre-adoption period (2005-2009);

- $\quad$ for post-adoption period (2013-2017).

3) Definition of a 10-year amortisation schedule (and related constant annual payment) of the PA technology 'package'. This phase is aimed at defining the annual capital cost of the investment in PA.

4) Definition of the pre-adoption average total cost:

- $\quad$ per hectare (ha);

- $\quad$ per product unit, in tonne ( $\mathrm{t}$ ).

5) Estimation of the post-adoption monetary savings at a level of average total cost induced by PA adoption:

- $\quad$ per hectare (ha);

- $\quad$ per product unit $(t)$.

6) Estimation of the post-adoption average total cost (ATC):

- $\quad$ per hectare (ha);

- $\quad$ per product unit $(t)$

7) Definition of the market price time series (2012-2019) for durum and soft wheat.

8) Estimation of the operating margin generated by the adoption of the PA package:

- $\quad$ per hectare (ha);

- $\quad$ per product unit $(t)$.

9) Sensitivity analysis on the cost-benefit analysis results so as to evaluate the economic and financial effectiveness of the investment, according to the changes in

- $\quad$ production scale;

- unit product cost;

- land productivity.

\section{RESULTS}

Comparing the pre-adoption and post-adoption period of PATs, the main empirical evidence is relating to two main issues:

- the variation in land productivity;

- the change in cost.

Relating to the first aspect, as shown in Table 2, an increase in the average land productivity in the post-adoption period is observed.

In particular, the post-adoption land productivity enhancement is considerably greater in the case of soft wheat $(+23.3 \%)$ compared to the durum wheat (+14.2\%). Consequently, we decided to assess separately the supposed effect of PA in terms of economic effectiveness for both durum and for soft wheat.

In analysing the crop yield trends, it is not possible to establish with certainty whether this productivity enhancement is due to 
Table 2: Variation of crop yields over the entire study period

\begin{tabular}{lcccc}
\hline Crop & $\begin{array}{c}\text { Pre-adoption } \\
\mathbf{2 0 0 5 / 2 0 0 9} \\
\text { Average yield } \\
\text { (t / ha) }\end{array}$ & $\begin{array}{c}\text { Post-adoption } \\
\mathbf{2 0 1 3 / 2 0 1 7} \\
\text { Average yield } \\
\text { (t / ha) }\end{array}$ & $\begin{array}{c}\text { Increase } \\
\text { (t / ha) }\end{array}$ & $\begin{array}{c}\text { Increase } \\
\text { (\%) }\end{array}$ \\
\hline Durum W. & 5 & 5.71 & 0.71 & 14.2 \\
Soft W. & 5.93 & 7.31 & 1.38 & 23.3 \\
\hline
\end{tabular}

the technological change. We are aware that crop productivity is influenced by a complex set of factors, such as climatic conditions or the type of grain variety, certainly not only by the possible introduction of a specific technology. However, it must be noted that the increase in land productivity is measured over a five-year post-adoption period on average, which is a fairly reliable period to assume the presence of some level of impact from the introduced technology. Indeed, the improvement of crop yields could be associated with both the direct and indirect effects of PATs. The direct effects derive from the optimisation of production processes. The indirect effects derive from greater knowledge about the state of soils and crops. In this way, the farmer can make more timely decisions. In fact, the farmer in this case study stated that the georeferenced mapping of both the farmlands and working time allowed them to quantify how much of the farm area was actually worked upon due to overlapping errors from different cultivation operations. Further, both the mapping of production and the soil analysis allowed the farmer to optimise seeds, fertilisers and herbicides according to the real need of the plants and the productivity of the soils.

To evaluate the effect on production costs due to the introduction of PATs, the pre-adoption and post-adoption ATC have been estimated and then compared. In summary, Table 3 shows a comprehensive picture of the PA cost-benefit analysis results.

The pre-adoption ATC equalled $794.56 € /$ ha for durum wheat and equivalent to $768.98 € /$ ha for soft wheat. Further, the average saving (AS) on ATC in the post-adoption period, hypothetically attributable to the cost efficiency of the PATs, was found to be $77.55 € /$ ha, a cost reduction of $10.08 \%$ on average compared to ATC in the pre-adoption period. In particular, through the use of fertiliser spreaders, machines for weeding and treatments, and seeders with variable dosage distribution, it was possible to reduce the cost of mechanical operations (labour, diesel, lubricants, etc.) and technical means (spreading seeds, fertilisers and pesticides). However, in order to evaluate the net

Table 3: Cost-benefits analysis results

\begin{tabular}{lrr}
\hline Cost & \multicolumn{1}{c}{ Soft W. } & Durum W. \\
\hline ATC pre-adoption (per hectare) & $768.98 € /$ ha & $794.56 € /$ ha \\
Average saving on ATC (per hectare) & $-77.55 € /$ ha & $-77.55 € /$ ha \\
Incidence capital cost (per hectare) & $44.08 € /$ ha & $44.08 € /$ ha \\
Incidence capital cost (per tonne) & $6.0 € / \mathrm{t}$ & $7.7 € / \mathrm{t}$ \\
$\begin{array}{l}\text { Average saving on ATC due to PA cost } \\
\text { efficiency (per hectare) }\end{array}$ & $-33.47 € /$ ha & $-33.47 € /$ ha \\
$\begin{array}{l}\text { Average saving on ATC due to PA cost } \\
\text { efficiency (per tonne) }\end{array}$ & $-4.6 € / \mathrm{t}$ & $-5.9 € / \mathrm{t}$ \\
$\begin{array}{l}\text { Total average saving on ATC (per } \\
\text { tonne): cost efficiency plus productivity } \\
\text { effect }\end{array}$ & $-29.0 € / \mathrm{t}$ & $-25.5 € / \mathrm{t}$ \\
ATC pre-adoption (per tonne) & $\mathbf{1 2 9 . 6 € / \mathbf { t }}$ & $\mathbf{1 5 8 . 6} € / \mathbf{t}$ \\
ATC post-adoption (per tonne) & $\mathbf{1 0 0 . 7} € / \mathbf{t}$ & $\mathbf{1 3 3 . 1} € / \mathbf{t}$ \\
\hline
\end{tabular}

savings due to PA adoption, the capital cost (CC) of the technology introduced has to be estimated and then discounted from the average savings on the operating production costs. Thus, a 10-year amortisation schedule at a $5 \%$ annual interest rate (plus related constant annual payments) of the introduced PATs package has been calculated. We calculated a CC of the total investment in PATs to be $44.08 € / \mathrm{ha}$, calculated based on the agricultural area invested in the cereal production within the case study, i.e. 537 ha. We then calculated the net savings (NS) per hectare on the production cost, hypothetically due to the technology package introduced, as follows:

$$
\mathrm{AS}-\mathrm{CC}=\mathrm{NS}=33.47 € / \text { ha }
$$

Thus, when CC is deducted from the total cost reduction (or AS) between pre- and post-adoption ATCs, a reduction of $10.08 \%$, the total NS is $4.3 \% / \mathrm{ha}$. The first interesting notion is that this net effect of PA in terms of cost efficiency is relatively modest and in line with the previous studies examined in the literature review. A possible explanation is the fact that the case study farm is an entrepreneurial farm, already fully functional before PA adoption with a high level of efficiency with respect to the cost of production per unit of land. That said, the most significant effect attributed to PA seems to concern productivity.

Finally, to measure the net gains per unit of production in the post-adoption period, the operating margin $(\mathrm{OM})$ per tonne of production has been calculated as the percentage difference between the average revenue (AR) - corresponding to the average market price for the period considered - and the ATC as follows:

$\mathrm{OM}(\%)=(\mathrm{AR}-\mathrm{ATC}) / \mathrm{AR}$

Table 4 shows the main indicators from the PA cost-benefit analysis. The $\mathrm{OM}$ increases from $40.5 \%$ in the pre-adoption period to $50.1 \%$ in the post-adoption period for soft wheat while it increases from $42.9 \%$ in the pre-adoption period to $55.7 \%$ in the post-adoption period for durum wheat. This performance is due almost entirely to the increase in land productivity registered for the post-adoption period.

Table 4: Cost-benefits analysis indicators

\begin{tabular}{|c|c|c|}
\hline Indicators & Soft W. & Durum W. \\
\hline $\begin{array}{l}\text { Land productivity increase post- } \\
\text { adoption }\end{array}$ & $23.18 \%$ & $14.13 \%$ \\
\hline Average saving on ATC (\%) & $10.08 \%$ & $10.08 \%$ \\
\hline $\begin{array}{l}\text { Average saving on ATC (\%) net of the } \\
\text { CC }\end{array}$ & $4.3 \%$ & $4.3 \%$ \\
\hline $\begin{array}{l}\text { Total average saving on ATC (per } \\
\text { tonne): cost efficiency plus land } \\
\text { productivity effect (\%) }\end{array}$ & $-22 \%$ & $-16 \%$ \\
\hline OM per tonne (\%) pre-adoption & $40.5 \%$ & $42.9 \%$ \\
\hline OM per tonne (\%) post-adoption & $50.1 \%$ & $55.7 \%$ \\
\hline $\begin{array}{l}\text { Net gains in monetary terms pre- } \\
\text { adoption }\end{array}$ & $114.8 € / t$ & $98.7 € / t$ \\
\hline $\begin{array}{l}\text { Net gains in monetary terms post- } \\
\text { adoption }\end{array}$ & $140.3 € / t$ & $127.7 € / t$ \\
\hline Net gains in monetary terms due to PA & $25.49 € / t$ & $28.97 € / t$ \\
\hline
\end{tabular}




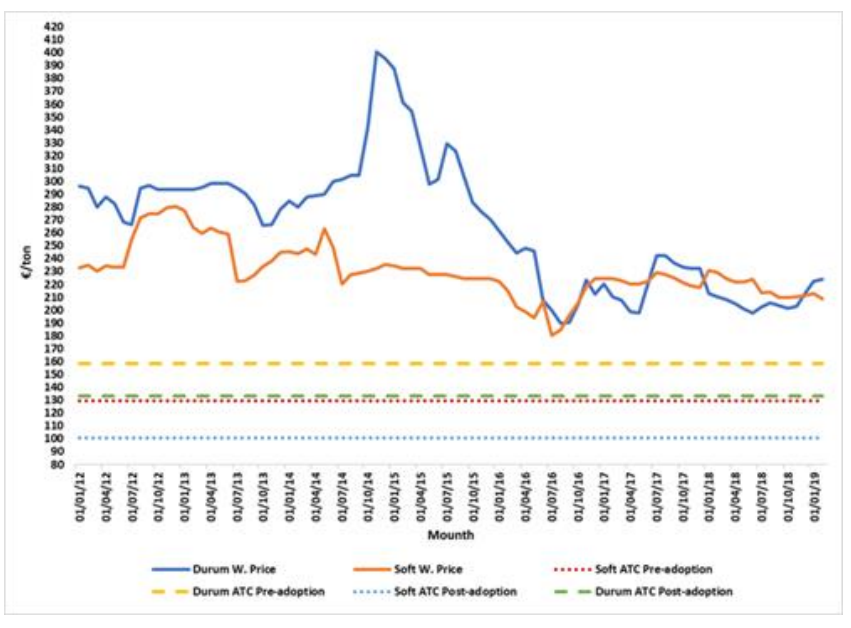

Figure 3. Prices and ATCs for soft and durum wheat

The $\mathrm{OM}$ is the summary result of this cost-benefit analysis; therefore, it seems important to offer some assessments on the basic meaning of this measurement. Looking at Figure 3, it is possible to visualise in a comparative way the net gains derived from the production of wheat in the pre-adoption period and the post-adoption period. The first interesting note is that we analyzed a farm able to generate income both for the preadoption (thus regardless of the PA adoption) and the postadoption period respect to Italian conventional cereal farms that are rarely effective. The second interesting note is that in the post-adoption period, the NS increases, in monetary terms, by $9.6 \%$ for soft wheat and $12.8 \%$ for durum wheat. This means, in absolute terms, the net gains in monetary terms is higher in the case of soft wheat (in both the pre-adoption and post-adoption periods). The increase of the operating margin due to PA (in \%) for durum wheat could be due to a more favourable average level of the durum wheat market price in the post-adoption period (as compared to the soft wheat market price).

A further consideration which may deserve more attention is the following: the present case study is a cooperative farm that dedicates more than 500 ha to the production of wheat. This means that the farm is a 'large farm' and that it can be roughly considered a case of minimum efficient scale, with respect to a fixed investment like the PATs package. For this specific case study, we observed that the impact of CC on the unit of production turns out to be minimised thanks to the optimal farm dimensions. However, if the farm size decreases, the impact of $\mathrm{CC}$ on the unit of product will increase accordingly. This occurs because, as we have verified, the cost of the PATs package can be considered, with good approximation, a fixed cost, not reducible depending on the reduction of the firm size. Based on this hypothesis, we performed a sensitivity analysis to explore the variation of the CC impact on ATC per unit of production with respect to changes in farm size. The goal of this sensitivity analysis was to identify the minimum farm size needed to balance

Table 5: Minimum farm size in balance

\begin{tabular}{lcc}
\hline Indicators & $\begin{array}{c}\text { Soft } \\
\text { scale } \mathbf{3 0} \text { ha }\end{array}$ & $\begin{array}{c}\text { Durum } \\
\text { scale } \mathbf{6 0} \text { ha }\end{array}$ \\
\hline Incidence capital cost / ha & $790.0 € /$ ha & $395.0 € /$ ha \\
Incidence capital cost / $t$ & $108.1 € / \mathrm{t}$ & $69.1 € / \mathrm{t}$ \\
ATC post-adoption (ha) & $1,481.4 € /$ ha & $1,112.0 € /$ ha \\
ATC post-adoption (t) & $202.7 € / \mathrm{t}$ & $194.5 € / \mathrm{t}$ \\
\hline
\end{tabular}

the farm budget, with respect to the post-adoption market price levels.

Table 5 shows the results of the sensitivity analysis performed on the balanced minimum farm size, assuming as constant all the variables considered in the present case study - i.e., the CC invested in the PATs package, the ATC of production per hectare, the average saving on ATC per hectare and the productivity levels; only production scale changed. The minimum production scale necessary to balance the farm budget appears to be strongly influenced by land productivity. Accordingly, based on a post-adoption soft wheat productivity level that is $22 \%$ greater than durum wheat $(7.3 \mathrm{t}$ vs. $5.7 \mathrm{t}$ ), the 'virtual' minimum production scale necessary to balance the firm budget results in 60 ha for durum wheat and 30 ha for soft wheat.

It is interesting to note that the minimum farm size required to balance the budget - in this case, regardless of the distinction between soft and durum wheat - is significantly smaller compared to the size of the real case study farm. This means that PATs could be financially sustainable even for 'medium' production scales when keeping the cost efficiency and productivity levels, as expressed by the study case farm, fixed.

Finally, as a further point of reference related to the minimum production scale necessary to obtain a positive result by adopting PATs, Table 6 illustrates a simulation consisting of the results of a sensitivity analysis to identify the minimum farm size needed to balance the farm budget with respect to PAT adoption by a cereal farm producing durum wheat in a hilly area. Thus, the fundamental analytical elements that distinguish this 'virtual' farm from our real case study are as follows:

- Hilly area (vs. flat land for the case study);

- Minimum tillage (vs. no tillage for the case study).

- Unit cost of production equal to $170 € / \mathrm{t}$ (vs $133.1 € / \mathrm{t}$ for the case study);

- Land productivity equal to $5 \mathrm{t} / \mathrm{ha}$ (vs. $5.7 \mathrm{t} / \mathrm{ha}$ for the case study)

The results show that the minimum farm size necessary to balance the farm budget is considerably greater than the minimum farm size for the case study farm (200 ha in a hilly area versus 60 ha in a flat area).

This result is indicative of how the economic effect of PATs changes as the environmental conditions, in which the production takes place, change. Particularly, in this hypothetical scenario characterised by minimum tillage of a hilly area, the unit production cost is assumed to be $35 \%$ greater than the unit production cost of the case study farm, and the land productivity level is assumed to be $15 \%$ lower. Based on these results, one can conclude that PA adoption in a hilly area using minimum tillage could be worth the investment only for large farms (>200 ha) or for cooperative systems capable of bringing together many producers in a common management organisation.

Table 6: Minimum farm size balance in hilly area

\begin{tabular}{lc}
\hline $\begin{array}{l}\text { Indicators based on ATC condition of } \\
\text { minimum tillage average cost (ha) and } \\
\text { hilly area }\end{array}$ & Durum 200 ha \\
\hline Incidence capital cost / ha & $118.5 € /$ ha \\
Incidence capital cost / & $23.7 € / \mathrm{t}$ \\
ATC cost post-adoption (ha) & $968.5 € /$ ha \\
ATC post-adoption (t) & $193.7 € / \mathrm{t}$ \\
\hline
\end{tabular}




\section{CONCLUSION}

PA may offer important opportunities toward more sustainable agriculture. However, the diffusion of PATs in the agricultural sector is still insufficient due to the scarce knowledge regarding economic and environmental benefits that PATs may have. In this regard, the case study in this work contributes to the body of research aimed at identifying important points of reference for cost-effectiveness and efficiency in PA-derived production inputs. The case study shows how a large farm can effectively exploit the returns to scale associated with adopting PATs packages, generating income as a consequence. Indeed, PA requires a large investment of capital, time and learning. Thus, costs associated with PATs may prevent smaller farms from being able to invest in these technologies. In this context, the farm-scale is a crucial variable in the analysis tools to evaluate the adoption and profitability of PATs. However, insofar as how PATs were able to reconcile production requirements and environmental protection, questions arise on how best to support PA adoption. It is clear that there are still no specific measures for the diffusion of PATs in the agriculture sector, but there are generic measures of sector innovation and digitisation of the agri-food chain.

While several studies have begun to demonstrate the economic effectiveness of PATs, the assessment and quantification of the environmental benefits are almost totally lacking in the literature. Some farmers do consider these benefits as part of their overall viability decision, but this is based upon their personal values. Apart from general qualitative statements, there is no quantified environmental benefit assessment that can underpin an investment decision; this appears to be a significant omission that could be addressed by developing a methodology and/or tool for the management decision-making process.

Finally, in PA, there is often a large knowledge gap between the technology companies and the farmers, and not enough effort is being spent on closing this gap. Future research will be focused on relationships between these providers and users.

\section{ACKNOWLEDGEMENT}

The authors wish to thank members of the Operational Group (OP) S.A.T. (SMART AGRICULTURE TEAM) Precision agriculture: reduction of the environmental impact of production systems (ID N²9000) - financed by RDP Marche 2014/2020, Submieasure 16.1. Support for the establishment and management of EIP operational groups on agricultural productivity and sustainability - and for the members of the research project 'PFRLab: Setting of a precision farming robotic laboratory for cropping system sustainability and food safety and security' - was provided by the Department of Agricultural, Food and Environmental Sciences (D3A), Università Politecnica delle Marche (UNIVPM).

\section{REFERENCES}

[1] E. C. Leonard, Precision agriculture, in: C. Wrigley, H. Corke, K. Seetharaman, J. Faubion (Eds.), Encyclopedia of Food Grains, vol. 4, Elsevier, Oxford, 2016, pp. 162-167.

[2] F. J. Pierce, P. Nowak, Aspects of precision agriculture, Advances in agronomy (vol. 67, pp. 1-85). Academic Press, 1999.

[3] J. V. Stafford, Implementing precision agriculture in the $21 \mathrm{st}$ century, Journal of Agricultural Engineering Research, 76(3), 2000, pp. 267-275.

DOI: https://doi.org/10.1006/jaer.2000.0577
[4] A. McBratney, B. Whelan, T. Ancev, J. Bouma, Future directions of precision agriculture. Precision Agriculture, 6(1), 2005, pp. 7 23.

DOI: https://doi.org/10.1007/s11119-005-0681-8

[5] R. Gebbers, V. I. Adamchuk, Precision agriculture and food security. Science, 327(5967), 2010, pp. 828-831.

DOI: https://doi.org/10.1126/science.1183899

[6] S. Fountas, K. Aggelopoulou, T. A. Gemtos, O. Precision Agriculture, in: E. Iakovou, D. Bochtis, D. Vlachos, D. Aidonis (Eds.), Supply Chain Management for Sustainable Food Networks, Wiley, 2016, ISBN: 978-1-118-93075-5.

[7] P. Wagner, Problems and potential economic impact of precision farming, in: Proceedings of the 7th International Congress for Computer Technology in Agriculture (ICCTA), 2000, pp. 241-249.

[8] A. P. Barnes, I. Soto, V. Eory, B. Beck, A. Balafoutis, B. Sánchez, J. Vangeyte, S. Fountas, T. wan der Wal, M. Gómez-Barbero, Exploring the adoption of precision agricultural technologies: A cross regional study of EU farmers. Land Use Policy, 80, 2019, pp. 163-174.

DOI: https://doi.org/10.1016/j.landusepol.2018.10.004

[9] G. Bucci, D. Bentivoglio A. Finco, Factors affecting ICT adoption in agriculture: a case study in Italy, Quality - Access to Success, vol. 20 (S2), 2019, pp. 122-129.

[10] M. Paustian, L. Theuvsen, Adoption of precision agriculture technologies by German crop farmers. Precision Agriculture, 18(5), 2017, pp. 701-716. DOI: https://doi.org/10.1007/s11119-016-9482-5

[11] A. Barnes, I. De Soto, V. Eory, B. Beck, A. Balafoutis, B. Sánchez, M. Gómez-Barbero, Influencing factors and incentives on the intention to adopt precision agricultural technologies within arable farming systems. Environmental Science \& Policy, 93, 2019, pp. 66-74.

DOI: https://doi.org/10.1016/j.envsci.2018.12.014

[12] T. Mancuso, T. Verduna, S. Blanc, G. Di Vita, F. Brun, Environmental sustainability and economic matters of commercial types of common wheat. Agricultural Economics, 65(4), 2019, pp. 194-202.

DOI: https://doi.org/10.17221/172/2018-AGRICECON

[13] M. Sozzi, A. Kayad, D. Giora, L. Sartori, F. Marinello, Costeffectiveness and performance of optical satellites constellation for Precision Agriculture, in: Precision Agriculture '19. Wageningen Academic Publishers, 2019, pp. 1-17.

[14] G. Codeluppi, A. Cilfone, L. Davoli, G. Ferrari, VegIoT Garden: a modular IoT Management Platform for Urban Vegetable Gardens. 2019 IEEE International Workshop on Metrology for Agriculture and Forestry (MetroAgriFor), 2019, pp. 121-126.

[15] W. E. Larsen, G. A. Nielsen, D. A. Tyler, Precision navigation with GPS. Computers and Electronics in Agriculture, 11(1), 1994, pp. 85-95.

DOI: https://doi.org/10.1016/0168-1699(94)90054-X

[16] E. Balestrieri, L. De Vito, F. Lamonaca, F. Picariello, S. Rapuano, I. Tudosa, Research challenges in measurement for Internet of Things systems. ACTA IMEKO, 7(4), 2018, pp. 82-94. Online [Accessed 23 September 2020] DOI: https://doi.org/10.21014/acta imeko.v7i4.675

[17] Z. Zhai, J. F. Martínez, V. Beltran, N. L. Martínez, Decision support systems for agriculture 4.0: Survey and challenges. Computers and Electronics in Agriculture, 170, 2020, 105256.

DOI: https://doi.org/10.1016/i.compag.2020.105256

[18] International Organization for Standardization (ISO), Tractors, Machinery for Agriculture and Forestry - Serial Control and Communications Data Network, Parts 1 to 5, 1997.

[19] S. M. Pedersen, K. M. Lind (Eds.), Precision Agriculture: Technology and Economic Perspectives. Springer International Publishing, 2017.

[20] J. Guo, X. Li, Z. Li, L. Hu, G. Yang, C. Zhao, M. Ge, Multi-GNSS precise point positioning for precision agriculture, Precision Agriculture, 19(5), 2018, pp. 895-911.

DOI: https://doi.org/10.1007/s11119-018-9563-8 
[21] M. Pérez-Ruiz, S. Upadhyaya, Chapter 1: GNSS in Precision Agricultural Operations, in: New approaches of indoor and outdoor localization systems, IntechOpen, London, 2012, ISBN: 978-953-51-0775-0, pp. 3-26. Online [Accessed 23 September 2020] DOI: https://doi.org/10.5772/2751

[22] Y. Vecchio, G. P. Agnusdei, P. P. Miglietta, F. Capitanio, Adoption of precision farming tools: the case of italian farmers, International Journal of Environmental Research and Public Health, 17(3), 2020, p. 869. Online [Accessed 23 September 2020] DOI: https://doi.org/10.3390/ijerph17030869

[23] H. S. Pathak, P. Brown, T. Best, A systematic literature review of the factors affecting the precision agriculture adoption process, Precision Agriculture, 20(6), 2019, pp. 1292-1316. DOI: https://doi.org/10.1007/s11119-019-09653-x

[24] T. B. Long, V. Blok, I. Coninx, Barriers to the adoption and diffusion of technological innovations for climate-smart agriculture in Europe: evidence from the Netherlands, France, Switzerland and Italy, Journal of Cleaner Production, 112, 2016, pp. 9-21.

DOI: https://doi.org/10.1016/i.jclepro.2015.06.044

[25] A. M. Ciruela-Lorenzo, D. Aguila-Obra, A. Rosa, A. PadillaMeléndez, J. J. Plaza-Angulo, Digitalization of Agri-cooperatives in the Smart Agriculture Context. Proposal of a Digital Diagnosis Tool. Sustainability, 12(4), 2020, p. 1325.

DOI: https://doi.org/10.3390/su12041325

[26] M. Cubric, Drivers, barriers and social considerations for AI adoption in business and management: A tertiary study. Technology in Society, Vol. 62, August 2020, 101257 DOI: https://doi.org/10.1016/i.techsoc.2020.101257

[27] Osservatorio PoliMI Smart AgriFood, L'agricoltura 4.0 in Italia: Domanda e offerta a confronto. Report, 2018

[28] C. Fabbri, M. Napoli, M. Mancini, G. Brandani, R. Vivoli, S. Orlandini, Adopting precision agriculture to improve the cultivation of old wheat varieties in Tuscany (Italy), in: Precision Agriculture '19. Wageningen Academic Publishers, 2019, pp. 309315.

[29] F. Morari, V. Zanella, L. Sartori, G. Visioli, P. Berzaghi, G. Mosca, Optimising durum wheat cultivation in North Italy: understanding the effects of site-specific fertilization on yield and protein content. Precision Agriculture, 19(2), 2018, pp. 257-277 DOI: https://doi.org/10.1007/s11119-017-9515-8

[30] P. Toscano, A. Castrignanò, S. F. Di Gennaro, A. V. Vonella, D. Ventrella, A. Matese, A precision agriculture approach for durum wheat yield assessment using remote sensing data and yield mapping. Agronomy, 9(8), 2019, p. 437. DOI: https://doi.org/10.3390/agronomy9080437

[31] S. Poni, M. Gatti, A. Palliotti, Z. Dai, E. Duchêne, T.-T. Truong, G. Ferrara, A. M. S. Matarrese, A. Gallotta, A. Bellincontro, F. Mencarelli, S. Tombesia, Grapevine quality: A multiple choice issue. Scientia Horticulturae, 234, 2018, pp. 445-462.

DOI: https://doi.org/10.1016/i.scienta.2017.12.035

[32] G. Blasi, M. Pisante, L. Sartori, R. Casa, S. Liberatori, F. Loreto, B. De Bernardinis, Linee guida per lo sviluppo dell'agricoltura di precisione in Italia. Rome, Italy, 2017.

[33] R. J. Godwin, T. E. Richards, G. A. Wood, J. P. Welsh, S. M. Knight, An economic analysis of the potential for precision farming in UK cereal production. Biosystems Engineering, 84(4), 2003, pp. 533-545.

DOI: https://doi.org/10.1016/S1537-5110(02)00282-9

[34] T. W. Griffin, J. Lowenberg-DeBoer, Worldwide adoption and profitability of precision agriculture Implications for Brazil. Revista de Politica Agricola, 14(4), 2005, pp. 20-37.

[35] R. Kingwell, A. Fuchsbichler, The whole-farm benefits of controlled traffic farming: An Australian appraisal. Agricultural Systems, 104(7), 2011, pp. 513-521. DOI: https://doi.org/10.1016/i.agsy.2011.04.001

[36] M. Robertson, P. Carberry, L. Brennan, The economic benefits of precision agriculture: case studies from Australian grain farms. Canberra, CSIRO, 2007, Retrieved March 12, 2012 from http://citeseerx.ist.psu.edu/viewdoc/download?doi=10.1.1.528. $5526 \&$ rep $=$ rep $1 \&$ type $=$ pdf

[37] G. Bucci, D. Bentivoglio, A. Finco, M. Belletti, Exploring the impact of innovation adoption in agriculture: how and where Precision Agriculture Technologies can be suitable for the Italian farm system?, IOP Conference Series: Earth and Environmental Science, vol. 275, no. 1, p. 012004, IOP Publishing, 2019. Online [Accessed 23 September 2020]

DOI: https://doi.org/10.1088/1755-1315/275/1/012004

[38] E. Pierpaoli, G. Carli, E. Pignatti, M. Canavari, Drivers of precision agriculture technologies adoption: a literature review. Procedia Technology, 8, 2013, pp. 61-69.

DOI: https://doi.org/10.1016/j.protcy.2013.11.010

[39] R. Bongiovanni, J. Lowenberg-DeBoer, Economics of variable rate lime in Indiana. Precision Agriculture, 2(1), 2000, 55-70. DOI: https://doi.org/10.1023/A:1009936600784

[40] R. J. Godwin, G. A. Wood, J. C. Taylor, S. M. Knight, J. P. Welsh, Precision farming of cereal crops: a review of a six year experiment to develop management guidelines, Biosystems Engineering, 84(4), 2003, pp. 375-391.

DOI: https://doi.org/10.1016/S1537-5110(03)00031-X

[41] J. T. Biermacher, B. W. Brorsen, F. M. Epplin, J. B. Solie, W. R. Raun, The economic potential of precision nitrogen application with wheat based on plant sensing. Agricultural Economics, 40(4), 2009, pp. 397-407.

DOI: https://doi.org/10.1111/i.1574-0862.2009.00387.x

[42] P. Wagner, M. Schneider, G. Weigert, The Use of Artificial Neuronal Networks to Generate Decision Rules for Site-Specific Nitrogen Fertilization. In ISPA (International Society of Precision Agriculture), Proceedings of the $11^{\text {th }}$ International Conference on Precision Agriculture [CD-ROM], 2010.

[43] M. J. Robertson, R. S. Llewellyn, R. Mandel, R. Lawes, R. G. V. Bramley, L. Swift, N. Metz, C. O'Callaghan, Adoption of variable rate fertiliser application in the Australian grains industry: status, issues and prospects. Precision Agriculture, 13(2), 2012, 181-199.

DOI: https://doi.org/10.1007/s11119-011-9236-3

[44] J. Shockley, C. R. Dillon, T. Stombaugh, S. Shearer, Whole farm analysis of automatic section control for agricultural machinery. Precision Agriculture, 13(4), 2012, pp. 411-420. DOI: https://doi.org/10.1007/s11119-011-9256-z

[45] N. Zhang, M. Wang, N. Wang, Precision agriculture - a worldwide overview. Computers and Electronics in Agriculture, 36(2-3), 2002, pp. 113-132. DOI: https://doi.org/10.1016/S0168-1699(02)00096-0

[46] R. Orsini, D. Basili, M. Belletti, D. Bentivoglio, C. A. Bozzi, S. Chiappini, C. Conti, A. Galli, E. Giorgini, M. Fiorentini, E. S. Malinverni, A. Mancini, L. Mazzanti, E. Monaci, G. Passerini, C. Pro, R. Santilocchi, A. Vignini, S. Zenobi, P. Zingaretti, Setting of a precision farming robotic laboratory for cropping system sustainability and food safety and security: preliminary results, IOP Conference Series: Earth and Environmental Science, vol. 275, no. 1, p. 012021, IOP Publishing, 2019. Online [Accessed 23 September 2020] DOI: https://doi.org/10.1088/1755-1315/275/1/012021

[47] R. Kingwell, A. Fuchsbichler, The whole-farm benefits of controlled traffic farming: An Australian appraisal, Agricultural Systems, 104(7), 2011, pp. 513-521.

DOI: https://doi.org/10.1016/j.agsy.2011.04.001

[48] B. C. Atherton, M. Morgan, S. A. Shearer, T. S. Stombaugh, A. D. Ward, Site-specific farming: A perspective on information needs, benefits and limitations, Journal of Soil and Water Conservation, 54(2), 1999, pp. 455-461.

[49] J. Lowenberg-BeBoer, Economics of precision farming: payoff in the future. Soil Science News and Views, vol. 18, no. 5, 1997. Online [Accessed 23 September 2020] https://uknowledge.uky.edu/pss views/16

[50] S. M. Swinton, J. Lowenberg-DeBoer, Evaluating the profitability of site-specific farming, Journal of Production Agriculture, 11(4), 
1998, pp. 439-446.

DOI: https://doi.org/10.2134/jpa1998.0439

[51] R. K. Roberts, B. C. English, S. B. Mahajanashetti, Evaluating the returns to variable rate nitrogen application, Journal of Agricultural and Applied Economics, 32(1), 2000, pp. 133-143. DOI: https://doi.org/10.1017/S1074070800027887

[52] D. Lambert, J. Lowenberg-De Boer, Precision agriculture profitability review. Purdue Univ., 2000.

[53] M. T. Batte, M. W. Arnholt, Precision farming adoption and use in Ohio: case studies of six leading-edge adopters. Computers and Electronics in Agriculture, 38(2), 2003, pp. 125-139 DOI: https://doi.org/10.1016/S0168-1699(02)00143-6

[54] J. Lowenberg-DeBoer, Risk management potential of precision farming technologies. Journal of Agricultural and Applied
Economics, 31(2), 1999, pp. 275-285.

DOI: https://doi.org/10.1017/S1074070800008555

[55] P. R. Tozer, Uncertainty and investment in precision agricultureIs it worth the money? Agricultural Systems, 100(1-3), 2009, pp. 80-87.

DOI: https://doi.org/10.1016/j.agsy.2009.02.001

[56] Y. Vecchio, M. De Rosa, F. Adinolfi, L. Bartoli, M. Masi, Adoption of precision farming tools: A context-related analysis. Land Use Policy, 94, 2020, 104481.

DOI: https://doi.org/10.1016/i.landusepol.2020.104481

[57] R. K. Yin, Case Study Research: Design and Methods. Beverly Hills, Calif: Sage Publications, 1984. 